\title{
THE LAW SCHOOL OF THE FUTURE: FROM LEGAL REALISM TO POLICY SCIENCE IN THE WORLD COMMUNITY
}

\author{
- MYRES S. MEDOUGAL*
}

(The following address was delivered before the Yale Law School Association on June I7, 1947. In the first section, entilled "From Legal Realism to Policy Science," Professor McDougal summarizes a proposed rcorientation of legal education. In the second section, "Objectives at Yale," Professor McDougal indicates the present impact of this proposed reorientation on the Yale Law School curriculam. The Editors of the JourNAL wish to thank the Yale Law School Association for the opportutrity of presenting to a wider audience Professor McDougal's vieu's on the function of the law school.)

\section{From Legal Realism to Policy Science}

\section{I}

For several decades the Yale Law School, like a number of other schools, has been inspired by, and has offered effective leadership in a philosophic movement known as legal realism.

The chief contribution of this movement has been to establish the fact that the doctrines, the verbal propositions, commonly called law are meaningful only when located in the total context in which they are being used-in the community process in which people are using these doctrines to effect, or justify, some specific distribution of values.

I do not scorn this movement, though I submit, and expect to show, that, taken alone, its attitudes and methods are not adequate to the opportunities and obligations of our time.

\section{II}

To appreciate fully the contribution of legal realism, we must recall the tremendous confusion in legal thinking and action with which it has had, and still has to cope.

This confusion has its roots deep in the distinctive language of the law. This distinctive language has long confused three completely different references:

(1) references that are naturalistic-statements of fact;

(2) references that are preferential-statements of the preferred events, of the values, sought by the speaker;

(3) references that are syntactic-statements of the formal, internal relationship of legal symbols and propositions.

Because of this confusion of reference, the propositions of our dis-

* William K. Townsend Professor of Lav, Yale School of Iaw. 
tinctive legal language are still too often considered as, at once, a summary of what officials have done, of what they will do, and of what they should do. The more important symbols of this distinctive language, even when restated by the American Law Institute, make a hopelessly indiscriminating reference to the facts of a controversy, to the identifications and demands of the parties, to relevant and irrelevant policies, and to applicable or inapplicable authoritative pronouncements. In their references to facts, these symbols still, to add further confusion, too often commingle the very different perspectives of the parties, the officials, and disinterested observers.

In recent years, the attitudes of observers toward this distinctive language of the law have varied between two polar extremes. At one extreme the uncritical assume that this language has some peculiar, compulsive, autonomous control over social processes-over relations between people-independently of concrete power structures, personalities, and other aspects of the immediate context. At the other extreme cynics deride this language as meaningless. In such extremes of ignorance, it is not surprising that there has been little understanding of the role that authoritative doctrine does, and can be made to play, among other interdependent variables, in affecting individual behavior and social processes in the distribution of values. It is not surprising, further, that little effective effort has been made, on many of the most urgent problems of our time, to clarify community values and to identify the conditions and means of their achievement.

\section{III}

To pose in sharpest outline the opportunities and obligations of the law school of the future, it may be helpful now to recall the conditions under which all this confusion arose and to note how such conditions have changed.

It may need emphasis that this confusion has been inherited from a time when we had less highly developed intellectual skills, when we were living in a completely different world, a world of completely different interdependences, and when attitudes toward the proper role and function of law in a community were very different.

This confusion was inherited from a time when people had no realistic understanding of psychology and personality, of how the human mind works, of how it uses words and other symbols, of the basic impulses of the human organism and the patterns of adjustment it makes to differing external stimuli, of how values, demands, identifications, and expectations are structured, consciously and unconsciously, into personality.

From a time when people were unaware of how to clarify values, but labored rather with endless and circular derivations from a metaphysics 
which posed unanswrerable questions and asked for their resolution by methods upon which no two observers could agree.

From a time when people had a minimal insight into group behaviour, social processes, and community institutions, and into the methods by which the conditions and trends, relevant to prediction and control, could be studied. When scientific study of social phenomena was sometimes conceived as a mere quantitative study of movements, without regard to the personalities of the observed and the communications they make to each other.

\section{IV}

This confusion in legal thinking and action was inherited from a time -to draw the broader context-when western European civilization was successfully expanding its colonization over the four corners of the globe, annihilating all who resisted or subordinating them as dependents to its imperial power.

It was a time when the way of life which we know as private enterprise, with a minimum of community coercion, was free of any deep concern for its own future.

When men could pursue, secure, and preserve wealth, and use private wealth as a base for affecting the distribution of other values in the community, without too much regard for their effects on the community or how the community was likely to respond.

When men could pursue power and take for granted the stability of the framework within which they worked, without too much concern for the continuation of the values which gave them their power.

When men could pursue enlightenment after their own bent, without regard for the consequences-when men could smash an atom without expecting to smash mankind.

When every intellectual and artistic skill could be concerned with itself and its own idiosyncrasies, with a minimal regard for the community process which produced it and which it in turn affected.

When men could demand respect for themselves, without too much sensitiveness to the claims of others.

When differing conceptions of morality, of right, were developing with a minimum of effort at harmonizing the differences.

It was a time, in still more general statement, of intellectual and moral specialization and atomization, of the pluralization of interests, when each interest made demands for itself with scant consideration of the social context-a time when there could be elaboration for elaboration's sake and specialization for specialization's sake.

When every person, as well as every group and nation, felt relatively secure in pursuit of its own special interests, unconcerned with the larger whole of society.

When people still felt-despite tremendous innorations and changes 
in technology, in institutions, and in values-no imperative need to assimilate and integrate the great transformations they were experiencing.

\section{V}

Turning now to attitudes toward law, it was a time when law was regarded as legal doctrine only, a peculiar set of technical symbols, and not as the whole of a community's institutions of government, both formal and real-the sum of all the power decisions of the community.

When people ascribed to law only the rather primitive function of maintaining order and did not think of it as a positive instrument for promoting and securing all the basic values of the community.

When the court was regarded as the principal and only proper instrument of legal control, without imaginative consideration of the whole range of institutions and practices that can be created, improved, or rearranged for securing community values.

When the full role of the lawyer in the community-his impact on policy-advising and policy-making and, hence, on the extent to which a community can achieve its values-was not clearly apparent.

\section{VI}

It needs no emphasis that this is a time which has gone forever.

We all sense today that a very profound change has come over the world. The safety of our country and of mankind as a whole is in greater peril than at any time in history. With this peril to safety, there is, of course, peril to all of our other values. Those of us who cherish a way of life which preserves a maximum of private volition, free from community coercion, can view the future only with the deepest concern.

For this country, the two problems of overwhelming urgency are, first, to preserve our domestic strength and prevent economic depression and, secondly, to preserve our power position and handle our power negotiations in the world community with such effectiveness that we can force a compromise with competing ways of life that will remove the anti-democratic elements, the elements that destroy human dignity, from all.

If there is anything clear today, it is that we cannot achieve qur own goals by acting alone and in splendid isolation from our effects on the rest of the world, and the effects of the rest of the world on us. We all know today that there is "a clear planetary indivisibility" 1 of all peoples everywhere, not only as to the minimum value of physical safety, but as to all values-the sharing of power, the production and sharing of wealth, well-being, enlightenment, health, and respect. Men no

1. Schernan, The Last Best Hope of Earth 15 (1941). 
longer ask for whom the bell tolls. They know it tolls for one and all. They are coming more and more to identify themselves and their interests, demands, and expectations, with all the communities-from local to global - to which they belong. The age of specialization for specialization's sake, of atomization, of pluralization, of sublime indifference, has gone.

With this new appreciation of community and interdependence there is coming also a new appreciation of the role that law can play as a positive instrument of community values-an appreciation of what can be achieved by bringing the important power decisions of the community under real as well as formal community control, and of the rich potentialities that inhere in bringing the best skills and enlightenment of the community to bear on these decisions. People everywhere are beginning to demand more perfect community instruments. They are beginning to show also a necessary willingness to experiment and to give up sentimental attachments to outmoded institutions, practices, and doctrines. Their clear call is for the creation of a law appropriate to the atomic era.

\section{VII}

It is, therefore, the opportunity, and the obligation, of this law: school, as of other schools, to emerge from the destructive phase of legal scholarship-indispensable though the destruction was-and to center its energies upon conscious efforts to create the institutions, doctrines and practices of the future.

The time has come for legal realism to yield predominant emphasis to policy science, in the world community and all its constituent communities. It is time for corrosive analysis and inspired destruction to be supplemented by purposeful, unremitting efforts to apply the best existing scientific knowledge to solving the policy problems of all our communities.

It is fortunate that today the necessary intellectual skills and enlightenment are at the disposal of any school that wishes to take advantage of its opportunities.

We have a psychology which is daily working new miracles in the understanding of the mind, in disclosing the secrets of personality formation, and in delineating the variables that affect behavior.

We know today how to clarify values into blue-prints for action, without either getting lost in the obsessive elaboration of meaningless absolutes or spending our energies in futile controversy over the relative merits of equivalent means.

We have today a social science that can achieve enough precision in the study of the environmental variables that affect human behavior to found wise policy judgment, without requiring impossible and in- 
terminable investigations and without frittering away resources and energies in concern over pedantic trivialities.

\section{Objectives at Yale}

It is no doubt superfluous to state that we in this school intend to take advantage of our opportunity and expect to bring to bear, upon the important problems of this new era, all the skills and enlightenment which our resources will permit. We are conscious of our obligation, we have the insight to know what we want and need, and we have confidence in our capacity to do significant work. Though our plans are just in their inception and we have only begun to assemble the necessary skills and staff, we are well beyond the blue-print stage. The level of our aspiration, the range of our interests, the skills we expect to bring to bear, and the energy we intend to spend, may be indicated by reference to a number of recent curricular announcements and proposals:

Beginning with the curriculum announcement for the 1947 Summer Term, I find:

"Recent Scientific Developments and the Law.

The scope and purpose of the course is to consider some of the major implications of the McMahon-Douglas Atomic Energy Act and general legal problems raised by this measure for the domestic control of atomic energy. The legislation raises issues of novelty, but, more important, issues of the broadest significance for our social, economic, and political systems.

Among the topics to be considered in lectures and discussions are the following:

1. Effect of the release of atomic energy on established economic institutions.

2. Atomic energy as a "socialist island" in a free enterprise system.

3. The Atomic Energy Act in its relation to general administrative practice. The Atomic Energy Commission as a quasi-legislative and quasi-judicial agency.

4. Civil liberties and the control of information.

5. The general control problem.

6. Fissionables as a new legal entity.

7. Atomic energy and patents.

8. Federal research policies and science under government.

9. Relation between domestic and international control of atomic energy.

10. Industrial uses of atomic energy and their legal aspects."

Looking back through the document, I see such items as:

"Legal Principles of Competitive Economics.

A study of the operation of the economy and of business practices in the light of the legal principles and problems which are incident 
thereto. Consideration will be given to general theories and specific practices which characterize our economy and which arise in the conduct of industrial and financial enterprises. The interrelationship of these theories and practices with legal theories and specific legislation and court decisions will be discussed."

\section{"Legal Accounting and Financral Analysis.}

The course is designed to integrate law and accounting by examining the areas of rapprochement and divergence in the context of legal issues. The first part of the course will acquaint the non-accountant with the techniques and disciplines of bookkeeping. The present applications of these techniques will then be reviewed principally in the fields of financial statement analysis, controls by and of the corporation, public utility regulation, and a general selection of litigation involving accounting concepts. Underlying the course will be an attempt to test the utility of 'generally accepted accounting principles' as a legal norm."

\section{"Case Presentation and Negotiation.}

Study and practice in presentation of cases before courts, administrative agencies, arbitration boards, and legislative committees. Special attention also is given to the techniques of negotiation with opposing counsel."

"French Comparative Law.

The objective of the seminar will be to familiarize students trained in the common law with the approaches and techniques of a civil law jurisdiction."

\section{"River Valleys of AMrerica.}

A study of the legal problems arising out of the planning for and execution of a program to utilize the natural resources of a major river valley region. In addition to general discussion of the problems, students will undertake individual studies of particular valley projects. . . . It is hoped that eventually a symposium for publication will result."

\section{"The World CoMmunity ANd Law.}

Law and science as instruments for maximizing representative values [well-being, (safety, health, character) wealth, shared power, respect, enlightenment, skill] in the world community. . . ."

Elsewhere, the speaker and his collaborator, Professor Lasswell, have described the latter course more fully as The World Communily and Law: International and Comparatiz'e Law to Promote the Policies of the World Community, stating, 
"We assume that there is today a world community in the fundamental sense that all peoples, whatever their location or function, are interdependent in achieving all the major values of our time-safety; the democratic sharing of power, respect and knowledge; the production and sharing of wealth; the promotion of congenial personal relationships; and the maintenance of standards of rectitude. We recognize, however, that this world community is imperfect in that pcoples are not yet fully conscious of these interdependences and have not yet reshaped their institutions to conform to the imperative requirements of these interdependences, and so to release their full potentialities in the production of values.

"It is our purpose to investigate the conditions under which the peoples of the world can be brought to a fuller consciousness and understanding of these interdependences and hence to shape the appropriate institutions.

"The conditions to be studied include, formally stated, the predispositions and environments of peoples the world over. The predispositions of people include the structures of demands, expectations and identifications with which they approach environments. Their environments may be described in terms of a hierarchy of communities-from neighborhoods through metropolitan communities and regions to nations and the world community -in which the representative values are differently distributed and hence present differing degrees of interdependence.

"In investigating these conditions it is our purpose to bring to bear all of the resources of modern psychological and social insight and skill, including the techniques of the newer and critical approaches to the study of law.

"Imaginative exploration of alternatives must include appraisal of institutions and practices, both governmental and private, from global organizations to the personal programs of people who share the same preferences. The institutions, practices and doctrines traditionally known as international law will require a reassessment and a determination of the extent to which they promote or retard the world community, with suggestion of appropriate improvements and alternatives. The study of comparative law as an investigation of the distribution of power and other values in the component communities of the world community can be given a new meaning and fruitfulness."

To give authentic notion of the range and variety of work being undertaken, I read a page titled "Seminars and Honors Work" from the curriculum announcement for the Fall Term 1947. For sake of caution $I$ interject that a previous page presents a series of courses attempting to place all the traditional vocational work of the school in appropriate functional contexts. The list of seminars reads :

Admiralty

Air Transportation
Case Presentation and Negotiation Communication and Law 
Corporate Readjusiments, Mergers, and Consolidations

Criminal Law and Public Order

Current Problems in Estates and

Trust Administration in Connecticut

Declaratory Judgments

Fact-Finding

Labor Law II

Labor Relations

Law and the Arts

Law, Science, and Policy
Law and the Industrial Paltern

Legal Aspects of Public Heallh, and Welfare Adninisistration

Legal Hislory

Political and Civil Rights

Public Control of Business IV:

The Control of Compelilion

River Valleys of America

Security Regulation

Theories of Law

Workshop in Public Control

The full description of the course on Law, Science, and Policy may give brief indication of one kind of inquiry which is deemed necessary to bring the best knowledge of the policy sciences to bear on contemporary legal problems. This reads:

"Law and science as instruments of public and private policy, with reference to selected problems of property and politics. The seminar is designed to test and to apply an analysis of the legal process outlined in publications by the directors of the seminar. New problems are selected each term in order to avoid duplication.

"In the fall term emphasis will be on legal semantics. The distinctive language of the lawyer will be studied in the perspective of what is now known about language as a whole and an effort vill be made to relate this distinctive language to the other variables that affect official behavior. Methods of forecasting appellate court decisions and opinions will be evaluated. Basic literature includes the work done and inspired by I. A. Richards, Rudolf Carnap, Edward Sapir, Charles W. Morris, Alfred Korzybski, and others.

"In the spring term emphasis will be on the interrelations of the decision-making process and the structure of personality and culture. The effect on official response of education, experience, temperament, and character will be explored. Basic literature includes the workdone and inspired by Max Weber, Mars, Pareto, Malinowski, Freud, Hull, Warner, Dollard, Fromm, and others."

To continue our illustration, some of the most effective work of the school is being done in the field of national economic policy. The most ambitious undertaking in this field is a new National Policy Seminar, an interdepartmental faculty seminar, including representatives of the departments of Economics and Political Science, as well as of the Law School. This Seminar is sponsoring research and publication on a number of urgent issues of national policy. Its immediate concern is with appropriate policies for implementing the Employment Act of 1946.

The undergraduate courses in this field of national economic policy, 
styled Public Control of Business, continue to proliferate in an apparently infinite series. The comprehensive conception which underlies these courses may be gathered from a statement by Professor Rostow, before the Association of American Law Schools, of what he and his collaborators are trying to do in the first course:

\begin{abstract}
"The traditional orientation of those materials is to have some cases on covenants not to compete, passing off, and trademarks and trade names; going on briefly into the field of the Sherman Act. That area of law is one of very great importance to practitioners at all levels of practice, but it is only a segment of the total machinery of our public law for the control of economic life.

"It seems to me essential that the study of such problems should be put in the wider framework of an analysis of our machinery for the control of economic life as a whole. The study of this branch of law should in my opinion give the student an understanding of the interrelationship of our various economic controls, and of the functions to which the banking system, the budget, the tax statutes, our wage policy, and the other branches of our public law for the control of economic life are being directed and should be directed, in order to produce an effective and stable economy.

"To undertake that kind of reorientation of the study of the public control of business does not require either an abandonment or an adherence to the case system as such. It requires, however, the accumulation of materials for the study of new problems in a different perspective, some of which are adapted to study by means of the case method and some of which are not adapted to study by means of the case method." 2
\end{abstract}

For final documentation I should like to refer to the program in Criminal Law and Public Order under Professor Dession's direction. This program is a striking example of what we mean by the policyscience approach to law and gives promise of becoming as richly creative as any work in the history of the School. It demonstrates, if demstration is still needed, that concern with policy and the utilization of related social science skills not only are not inconsistent with, but are actually indispensable to technical legal instruction on the highest professional level. The program includes a continuing project of research in the use of negative sanctions, in which Mr. Dession has enlisted the collaboration of a variety of social scientists and the support of a foundation interested primarily in anthropology. The viewpoint is as broad as possible, drawing on studies in comparative law and comparative history. The effort is to extend our knowledge of the use of criminal and other negative legal sanctions-the last resorts of any society against destructive order-disturbing tensions-so that they may

2. HandBook, The Association of American Law Schools 35 (1946). 
more effectively contribute to the promotion of our basic values. The effect is greatly to enrich instruction on the strictly professional level. Students in the various criminal law courses are introduced to the federal specialties in the field as well as the simpler criminal law of county administration. They are taught the procedure and the practice as well as the substantive law. For those who desire it advanced seminars on the graduate level in criminal legislative problems and in legal medicine are available. Once again concern with the larger aspects of a subject and a willingness to utilize allied skills result in the teaching of more, not less, law-and a law which effectively promotes basic community values.

These samples are enough, I hope, to show that our aspirations are not modest and that our emphasis is now primarily upon construction.

There is no reason why we cannot build in this Law School a great creative center for processing the best contemporary thought into programs for action, action to maximize the values of all our communities. (Here Professor McDougal refers to the peculiar advantages which the School has in terms of its location, officers, students, and alummi.)

With all of these advantages, we hope before too long to become a faculty which is worthy of its opportunities-a faculty which can draw upon the full experience of the past and which can bring the best methods of contemporary science, and the creative flash of insight, to the task of creating the law of the future.

This is what I mean when I suggest that the time has come to move from legal realism to policy science in the world community. 